\title{
DIVORCE REFORM AND FAMILY MEDIATION IN ENGLAND: AN OVERVIEW OF THE RELEVANT PROVISIONS OF THE FAMILY LAW ACT, 1996
}

\author{
Nora Abdul Hak* \\ Norliah Ibrahim**
}

\begin{abstract}
The article focuses on the divorce reform in England. In 1996, the Family Law Act was passed by the Parliament in England, which is cited as the Family Law Act, 1996. Unfortunately, after it was passed, there were problems concerning its enforcement and the Government decided to postpone the enforcement of some parts of the Act. Generally, the suspension involves the law concerning the ground of divorce and mediation. Although the overall position of the Act remains uncertain, it is significant to examine it because of its strength in upholding the institution of the family. Under the Act, mediation is introduced as it has many advantages such as resolving disputes amicably and it can reduce backlog of cases in the court. It is hoped that the discussion in this article will benefit Malaysia and hopefully we may learn something from the divorce reform that took place in
\end{abstract}

Associate Professor, Ahmad Ibrahim Kulliyyah of Laws, International Islamic University Malaysia.

Assistant Professor, Ahmad Ibrahim Kulliyyah of Laws, International Islamic University Malaysia. 
England. In Malaysia, the current Law Reform (Marriage and Divorce) Act 1976 has been enacted since 1976. Perhaps, we may introduce new family legislation governing non-Muslims and include mediation as an alternative means of resolving family disputes.

\section{INTRODUCTION}

The Family Law Act, 1996 (FLA, 1996) ${ }^{1}$ which has been described as the reform that never was, proposed to bring fundamental change to the law of divorce of England and Wales. Under this reform, mediation became part of the mainstream of the divorce process. Part II of the FLA, 1996 introduced a new concept of no-fault divorce. Formerly, the majority of divorce petitions were based on the respondent's adultery or "unreasonable behaviour." Under the new concept, the irretrievable breakdown of marriage would remain the sole ground for divorce, but without fault or blame being attributed to either party. It required married couples to attend information meetings before they can apply for divorce. This article discusses the relevant provisions on family mediation in English law. These provisions are contained in part II of the Family Law Act, 1996. Unfortunately the proposed new provisions have not yet come into force for reasons which will be considered in this article. The criticism against the new reform will also be briefly discussed.

\section{DIVORCE REFORM IN THE UK}

Reform in the current substantive and procedural laws arises from dissatisfaction with the procedures regulating divorce and the ineffectiveness of the reconciliation provisions under the Matrimonial Causes Act, 1973 (MCA, 1973). ${ }^{2}$ This led courts and practitioners to

\footnotetext{
$1 \quad$ Hereinafter the Family Law Act, 1996 is abbreviated as the FLA, 1996.

2 This stage of dissatisfaction with the law and procedure of divorce is discussed in, inter alia, The Booth Report, Report of the Matrimonial Causes Procedure Committee, London, HMSO, 1985; Roberts, M,
} 
introduce an alternative mechanism for helping couples to deal with the consequences of their divorce. ${ }^{3}$ In the Government's consultation paper, ${ }^{4}$ it is stated that the main criticisms of the then current law was as follows:

- $\quad$ the current divorce law does nothing to help save saveable marriages; ${ }^{5}$

- $\quad$ under the current law divorce can be obtained without proper consideration of the consequences and implications; ${ }^{6}$

- $\quad$ the system makes things worse for the children; ${ }^{7}$

Mediation in Family Disputes; Principles of practice, Arena, Ashgate Publishing, 1997, 50-52; Cretney, S and Masson, The principles of Family Law, Sweet and Maxwell, London, $4^{\text {th }}$ ed., 1984, 317-324; Bromley, Family Law, Butterworths, London, 9th ed., 1998, 235-240. The Matrimonial Causes Act 1973 will be abbreviated as the MCA, 1973.

3 This alternative mechanism is conciliation and later known as mediation. See, Bromley, Family Law, 232.

See, the Government Consultation Paper, Looking to the Future: Mediation and the Ground for Divorce, 1995, HMSO, Cm 2799 (This Consultation Paper will be abbreviated as The White Paper).

The current system provides little incentive or opportunity for reflection as to whether the marriage has indeed broken down irretrievably, or whether with appropriate help, the couple might wish to attempt to save the marriage. At present, once the petition has been filed, and the respondent has acknowledged service without intention to defend, parties may be divorced after a period of just a few months, having had few chances to stop and consider whether this is the best outcome for them and their children: The White Paper, paras. 2. 12-20. As under the current system divorce can be obtained within a short period of time it is thought that it would be desirable to encourage consideration before divorce, particularly with regard to matters of children, the matrimonial property and finance: The White Paper, para. 2.21 .

Research revealed that children suffer as a result of conflict between their parents. It is more damaging when parents either have to find fault with one another or live apart thus, there are long periods of uncertainty whilst things are sorted out. Furthermore the current process is 'adult-focused,' paying particular regard to the interest of the parents which often to the detriment of the children's welfare: The White Paper, paras 2.22-23. 
- $\quad$ the system is unjust; ${ }^{8}$

- $\quad$ it is confusing, misleading and open to abuse; ${ }^{9}$

- $\quad$ it is discriminatory; ${ }^{10}$ and

- $\quad$ the system distorts parties’ bargaining positions. ${ }^{11}$

Although both of the previous reports, Putting Asunder and Field of Choice anticipated that most couples would get divorced on the basis of the passage of time, this has not proven to be the case. ${ }^{12} \mathrm{~A}$ large majority of divorce petitions, i.e., about 75 per cent, are based on adultery or unreasonable behaviour, less than 20 per cent on two years separation, and fewer than 6 per cent on five years separation. ${ }^{13}$ Unreasonable behaviour is the most frequently cited ground as it is the quickest way of getting a divorce. ${ }^{14}$ There have been suggestion for the abolition increase

The present system, which is based on fault, construes the petitioner as the wronged party, and the respondent as the wrongdoer. This would be unjust if divorce is filed based on reasons, which are not typically 'faults' kind of reasons such as a mental illness or disability. Thus, the existing system was blamed for the above, the absence of practical opportunities for counselling and the adversarial legal system, which has brought hostility and bitterness: The White Paper, paras 2. 24-25.

Basically, the confusion about the current law comes from combining a ground for divorce i.e., irretrievable breakdown of marriage with the need to establish the irretrievable breakdown by reference to at least one of five specified facts, three of which do rely on allegations of fault. Thus this will open to abuse, as it is not necessary and rare in practice for allegations of fault to be corroborated: The White Paper, paras 2. 26-28.

The current system discriminates against those who do not have the financial means to separate and arrange separate accommodation before divorce. Thus the option of relying on the separation fact is closed to those of limited means, leaving allegation of fault as the only alternative: The White Paper, para. 2. 29. position may use his or her position to distort the negotiations related to children and finance for example, by a threat of withholding consent to divorce: The White Paper, 1995, para. 2.30. Law Act 1996, Grove Books Limited, Cambridge, 2000, 6. The White Paper, 1995, para. 2.4. 
the effectiveness of attempts to reconcile the parties. The petitioner will not be asked by his or her solicitor to write in detail the worst aspects of the respondent's behaviour. ${ }^{15}$

In their report, the Law Commission ${ }^{16}$ commented that the law and practice of divorce as provided for under the MCA, 1973 failed to give the parties an opportunity to come to terms with what was happening in their lives, to reflect in as calm and sensible way as possible upon the future, and to re-negotiate their relationship. ${ }^{17}$ The Commission also felt that the law failed to reflect the reality of divorce as a process, i.e., divorce was not a final product but rather a part of "a massive transition" for the parties and their children. ${ }^{18}$

\section{GOVERNMENT'S RESPONSES}

As a consequence of the dissatisfaction over the current state of affairs concerning divorce, Walker ${ }^{19}$ said, "divorce reform became a matter of some urgency in England.” After having consulted widely, the government in December 1993 published a consultation paper known as the Green Paper. ${ }^{20}$ This paper set out the defects of the existing law of divorce and proposed a new approach based on the Law Commission's concept of divorce as a "process over time" ${ }^{21}$ and with mediation

$15 \quad$ Price, David, 'Child Mediation in Private Law Cases-Reflections on the Consultation Document Supporting Families and the Related Paper Support Services (in Family Proceedings),' [1999] Fam Law, May 286.

16 The Law Commission Report, The Ground for Divorce, No 192, 1990; see also, Cretney, S, The Family Law, Sweet and Maxwell, London, $4^{\text {th }}$ ed., 2000, 64. The Law Commission Report, The Ground for Divorce, No 192, 1990. The Law Commission Report, The Ground for Divorce, No 192, 1990. Walker, J, 'Family Mediation’ in Macfarlane, J (ed.), Rethinking Disputes: the Mediation Alternative, Cavendish Publishing, 1997, 81. This happened particularly after enormous consultation and great care of Lord Mackay of Clashfern who was one of the great social reforming Lord Chancellors. He introduced very significant reform to the current process of divorce law.

Based on the concept that divorce as a process over time the Government accepted that the ground for divorce should be the 
provisions at the heart of the new divorce procedure. ${ }^{22}$ This was followed by the government's proposals for divorce law reform, which were published in April 1995 in the White Paper entitled Looking to the Future: Mediation and the Ground for Divorce. This paper sets out the proposed legislation on divorce reform and mediation, ${ }^{23}$ and it shows that responses on the Green Paper had shown strong support for family mediation. ${ }^{24}$ The White Paper listed ten major benefits of its proposals. They are:

- $\quad$ ensure that couples whose marriages are in difficulty will be better informed about the options available to them;

irretrievable breakdown of the marriage as demonstrated by the sole fact of a period for reflection and consideration. See, the White Paper, Cm 2799, para. 4. 7.

22 Roberts, M, Mediation in Family Disputes; Principles of practice, 24; Hayes, M and Williams, C, Family Law, Principles, Policy and Practice, $2^{\text {nd }}$ ed., Butterworths, 1999, 538-539.

This White Paper abolishes 'fault' in divorce itself. Under the new law divorce will be granted after one or both parties had attended a group information session and had indicated an intention to divorce. They must wait for a year before they can file divorce petition. During this period the parties are expected to reconsider whether their marriage can be saved and, if not they should face the consequences of their decision to divorce and make arrangements for their future apart. See, Shelley Day Sclater, 'A critical Approach to the White paper on divorce reform,' (1995) Web JCLI 2; See also, Walker, J, 'Family Mediation' in Macfarlane, J (ed), Rethinking Disputes: the Mediation Alternative, Cavendish Publishing, 1997, 82, where she described that the abolition of fault-based facts as evidence of breakdown has proved to be the most controversial element, and one which has deeply divided members of both Houses of Parliaments.

See, article by Chris Barton, 'The response to the Green Paper' (1994) Law Teacher, Spring, 28 n 2, 195-197; also article by Shelley Day Sclater, 'A Critical Approach to the White Paper on Divorce Reform' (1995) Web JCLI 2. Shelley in her paper discusses some of the issues raised by the Government proposals for reform of the divorce law. It included the responses of professional bodies i.e., the Law Society, the Solicitor's Family Law Association, and National Family Mediation to the green consultation paper. These responses are discussed in the light of the reform proposals put forward in the White Paper. 
- $\quad$ introduce a system that is better at identifying saveable marriages;

- $\quad$ facilitate referrals to marriage guidance when couples believe there may be some hope for the marriage;

- $\quad$ make available every opportunity to explore reconciliation even after the divorce process has started;

- $\quad$ ensure that there is an adequate period of time to test whether the marriage has genuinely broken down;

- $\quad$ remove the acrimony and hostility inherent in the current divorce process;

- minimise conflict and so reduce the worst effects of separation and divorce on children;

- $\quad$ help and protect children by encouraging parents to focus on their joint responsibility to support and care for their children;

- $\quad$ encourage couples to meet the responsibilities of marriage and parenthood before the marriage is dissolved;

- $\quad$ allow couples to make workable arrangements through family mediation in respect of their children, home and other matters following separation or divorce.

Walker ${ }^{25}$ agreed that the White Paper had introduced family mediation as a central component of the divorce process. She considered the proposals, as set out in the White Paper, as representing "a radical shift away from adversarial position towards an informal, individualised system of justice." The Law Society, ${ }^{26}$ however, in its considered response to the proposals set out in the consultation paper, sought to question the very basis and assumptions upon which those proposals were based. For example, it stated that an assumption that mediation works despite the lack of research evidence on this point and an assumption that divorcing people only need information and can do without advice. Thus, it recommended that there should be greater availability of mediation services in future, subject to the establishment of a regulatory framework, more research into the effectiveness of mediation, and proper funding. ${ }^{27}$

\footnotetext{
$25 \quad$ Walker, J, 'Family Mediation’ in Macfarlane, J (ed.), Rethinking Disputes: the Mediation Alternative, Cavendish Publishing, 1997, 81.

26 The Law Society, Fairness for Families: The Law Society's Response to the Consultation Paper, Law Society, London, 1994.

27 The Law Society, 1994; For a critical discussion of the White Paper, see, Shelley Day Sclater, 'The Limits of Mediation,' September [1995] Fam Law 494.
} 
On 15 November 1995, the Family Law Bill was announced in the Queen's Speech. This Bill finally received the Royal Assent in July $1996^{28}$ and was partially brought into force in $1999 .{ }^{29}$ In the FLA, 1996 mediation has enormous potential to minimise the adverse consequences of marital breakdown. Thus, it contains provisions to ensure that the parties are aware of the benefits offered by mediation, are given the opportunity to take advantage of mediation services, and if they are entitled, they can have the cost of mediation met from public funds. ${ }^{30}$ Several pilot studies to test out some of its provisions have been carried out. ${ }^{31}$

\section{THE FAMILY LAW ACT, 1996 AND PROVISIONS FOR MEDIATION}

\section{General description}

The FLA, 1996 which received Royal Assent on 4 July 1996 is widely regarded as one of the most radical and far-reaching reforms of family justice in this century. ${ }^{32}$ It is aimed at meeting the twin objectives

$28 \quad$ It has been described in many literature that the Bill had a difficult passage through parliament and some further changes were made to it from the original one. See, Bromley, Family Law, 240; see also, Cretney, S, Family Law, 65; Cretney, S and Roger, B, Divorce - The New Law, Family Law, Bristol, 1996, 8; Walsh, E, Hodson, D and Fisher, T, "Family Mediation-New Profession," in Thorpe and Clarke, E, No Fault or Flaw: The Future of the Family Law Act 1996, Family Law, 2000, 40; La Follette, Maryly and Purdie Robert, A Guide to the Family Law Act, 1996, Butterworths, London, 1996, 1.

29 It is to note that many aspects of the working of the law remain to be determined by statutory instruments and guidance. See, Bromley, Family Law, $8^{\text {th }}$ ed., 240.

30 Cretney, S, The Family Law, 69.

31 These pilot schemes have been undertaken with the objectives to make matrimonial proceedings more expeditious, less costly and less acrimonious.

32 Walker, J, 'Whither The Family Law Act, Part II,' in Thorpe and Clarke Elizabeth, No Fault or Flaw: The Future of the Family Law Act 1996, Family Law, 2000, 4; Black, J, Bridge, J and Bond, T, A Practical Approach to Family Law, Blackstone Press Ltd., London, $6^{\text {th }}$ ed., 2000, 166. 
of saving saveable marriages and promoting a conciliatory approach to divorce if divorce is the only option. This reform according to Bromley, "has now replaced all pretence that substantive law is involved, by overtly introducing a purely procedural set of hurdles which must be jumped in order to achieve the desired divorce order." 33

The present FLA, 1996 differs in many respects from the Bill originally introduced and even more from the Bill annexed to the Law Commission's report. Many aspects of the working of the law remain to be determined by statutory instruments and guidance, and pilot scheme have been launched to test these out before the new law is brought into force. ${ }^{34}$ The Act comprises four Parts and ten Schedules. Part I of the FLA, 1996 sets out the general principles underlying Parts II and III. Part II deals with divorce and separation. Part III deals with legal aids for mediation and the relationship between it and the provision of conventional legal services. Part IV covers occupation of the family home and domestic violence. These Parts have been implemented ${ }^{35}$ except Part II that covers divorce and separation and which contains the most extensive and perhaps controversial provisions. ${ }^{36}$

\section{The general principles underlying Part II and III}

The FLA, 1996 gives mediation a major role. As regards the role of mediation in the FLA, 1996 Brown $^{37}$ stated that "the FLA, 1996

\footnotetext{
$33 \quad$ Bromley, Family Law, $8^{\text {th }}$ ed., 223.

$34 \quad$ Ibid., 240.

35 The FLA, 1996 is still at the stage of progressive implementation. Parts I and III of the FLA, 1996 came into force on 21 March 1997 and Part IV in October 1997. However, part III was repealed by the Access to Justice Act, 1999 and the provisions governing the way in which public funding for mediation and related legal advice is available are now to be found in the community legal service scheme. Phase I of the Legal Aid Board Mediation Pilots and research relating to these pilots has been carried out. The first five-information meeting pilots were launched in June 1997 and a report of the results of these pilots has been presented to the Lord Chancellor in September 2000. See, Lord Chancellor Department, 16 January 2001; [1998] Fam Law 123.

$36 \quad$ House of Commons Hansard Debates, 4 April 2000, col. 948.

37 Brown, $\mathrm{H}$ and Marriott, A, ADR Principles and Practice, 224.
} 
introduced the concept of counselling and mediation as processes that stand alongside the legal process in dealing with the consequences of marriage breakdown.” Under the FLA, 1996 information about counselling and family mediation services is given at the preliminary information meeting. It includes also information about the divorce process and children's needs in divorce. ${ }^{38} \mathrm{At}$ the information meeting, those intending to divorce are encouraged to go to mediation to settle any or all issues, including arrangements for their children, financial support and division of property. ${ }^{39}$ If, after attending the information meeting, they still wish to seek a divorce, they must wait a minimum of three months before either party may file a statement of marital breakdown. ${ }^{40}$

Given the above as a snapshot of the current process of divorce, the FLA, 1996 requires the court, and any persons carrying out functions in respect of Part II and III of the FLA, $1996^{41}$ to have regard to the following general principles; ${ }^{42}$

- $\quad$ that the institution of marriage is to be supported;

- $\quad$ that the parties to a marriage which may have broken down are to be encouraged to take all practicable steps, whether by marriage counselling or otherwise, to save the marriage; ${ }^{43}$

- $\quad$ that a marriage which has irretrievably broken down and is being brought to an end should be brought to an end-

\footnotetext{
$38 \quad$ The FLA, s 8 (9).

39 See, the White Paper, para. 5.3.

The FLA, s 8 (2).

$41 \quad$ Part II comprises provision relating to divorce and separation and Part III provision relating to Legal Aid for mediation in family matters. These four fundamental principles are recognised by many involved in family issues as crucial to the better conduct of the work and to help families. See, Walsh, E, Hodson, D and Fisher, T, in Thorpe and Clarke, E, No Fault or Flaw: The Future of the Family Law Act 1996, 39.

43 According to McCarthy, Peter, et al., 'Saving Marriage - A Role for Divorce Law?’ [2000] June, Fam Law 413, there was scepticism about how many marriages would be saved from information meetings as a mean of preserving the institution of marriage. However, it is argued that the principle of saving marriage would be realistic if Part II of the FLA, 1996 were to be implemented. Thus, it is suggested that people should be encouraged to access information about marriage support services as early as they possibly could.
} 
○ with minimum distress to the parties and to the children affected;

○ with questions dealt with in a manner designed to promote as good a continuing relationship between the parties and any children affected as is possible in the circumstances; ${ }^{44}$

- without costs being unreasonably incurred in connection with the procedures to be followed in bringing the marriage to an end; and

- $\quad$ that any risks to one of the parties to a marriage, and to any children, of violence from the other party should, so far as reasonably practicable, be removed or diminished. ${ }^{45}$

The intention of these principles is to guide courts and others in their application of the provisions set out in the FLA, 1996. In this relation these others could include the Lord Chancellor, in drawing up the detailed regulations, lawyers, mediators, marriage counsellors and Legal Aid Board officials. ${ }^{46}$

In order to promote the above objectives, the FLA, 1996 as pointed out by Walker, ${ }^{47}$ removes the concept of fault as evidence of irretrievable breakdown. She further stated that the FLA, 1996 "acknowledges divorce as a process rather than a discrete event; it introduces a period of time for reflection and consideration; and requires that all arrangements for the future are made before divorce can be granted." ${ }^{48}$ To carry out the

Section 1(c) (ii) was introduced by further Government Amendment on the third reading of the Bill in the House of Lords on March 11, 1996. According to the Lord Chancellor (Official Report (H.L.) March 11, 1996, col. 618) that the object of adding this specific reference to the desirability of promoting continuity was to underline the fact that children have continuing needs and to dispel any suggestion that the children's needs and problems can be disposed of when the marriage is terminated. See, Cretney, S and Masson, The principles of Family Law, 327.

$45 \quad$ FLA, 1996, Part 1, s. 1.

$46 \quad$ Bromley, Family Law, $8^{\text {th }}$ ed., 240.

$47 \quad$ Walker, J, in Thorpe and Clarke E, No Fault or Flaw: The Future of the Family Law Act, 1996, 4.

48 Walker, J, in Thorpe and Clarke E, No Fault or Flaw: The Future of the Family Law Act, 1996, 4. 
above principles of the FLA, 1996, in March 1997 the Lord of Chancellor announced the establishment of a range of marriage support services including public funding for mediation.

The Act retains the general principle that the irretrievable breakdown of marriage is the only ground for divorce. ${ }^{49}$ However, it is further stated that such breakdown will be inferred, and can only be inferred from: ${ }^{50}$

- $\quad$ the lodging of a statement of marital breakdown with the court (which can only be done after attendance at an information meeting);

- $\quad$ the expiration after the making of the statement of a period for 'reflection and consideration;'51 and

- $\quad$ the making of an application for a divorce order. There must be evidence of compliance with the Act's requirements that the parties' arrangements for the future (in respect of children and financial matters) should first have been resolved ${ }^{52}$ and it must be accompanied by a declaration that the applicant believes the marriage cannot be saved..$^{53}$

\section{Relevant provisions on mediation}

The government in the White Paper has reached the view that greater use of mediation as part of the divorce process will help it achieve the objectives of a good divorce law. ${ }^{54}$ It is therefore important that, there should be a definite encouragement to couples to use family mediation. The government also recognised, inter alia, that through the mediation process, marriages which are capable of being saved, are more likely to be identified than through the legal process. ${ }^{55}$ Therefore,

\begin{tabular}{ll}
\hline 49 & The FLA, s 3(1) (a). \\
50 & Ibid., s 5 (1). \\
51 & Ibid., s 7 (1), (2). \\
52 & Ibid., s 3 (1) (c); s 9. \\
53 & Ibid., s 5 (1) (d). \\
54 & The White Paper, para. 5. 21. \\
55 & Ibid.
\end{tabular}


provisions to achieve this end were made in the FLA, 1996. The following discussion of these provisions is relevant to mediation.

\section{(a) Voluntary or mandatory}

Mediation under the FLA, 1996 is voluntary. ${ }^{56}$ However, couples should be better informed about mediation and be encouraged to use mediation in making future arrangements especially for the children. ${ }^{57}$ The FLA, 1996 requires that those seeking legally aided representation will (except in prescribed circumstances) be required to attend an exploratory meeting with a mediator to consider how mediation might help them. ${ }^{58}$

The government has stated in their 'White Paper' that mediation should be voluntary and not mandatory. ${ }^{59}$ They said that, "if both parties are not willing to try mediation, then it is not likely to be successful and thus valuable resources would be wasted." ${ }^{00}$ Under the FLA, 1996 referral

$56 \quad$ The Council of Europe adopted the principle that mediation should not, in principle, be compulsory. See, Recommendation No. R (98) 1 and Explanatory Memorandum, adopted by the Committee of Ministers of the Council of Europe on 21 January 1998, 9.

57 See, the White Paper.

58 Webley, L, A Review of the Literature on Family Mediation for England and Wales, Scotland, the Republic of Ireland, France and the United States, prepared for the Lord Chancellor's Advisory Committee on Legal Education and Conduct, 1998, pg. 21, views that this may result in "the legally eligible couples may attend mediation sessions because that is what they are expected to do under funding conditions, rather than as a result of a genuine willingness to embrace the mediation ethos."

$59 \quad$ The White Paper, 1995, para. 5.28. It has been stated in the Green Paper, Legal Aid-Targeting Need (1995) (para. 9.7) that:

"The Government does not believe that family mediation should be compulsory. Family mediation is a process that is unlikely to work effectively unless couples enter it voluntarily."

$60 \quad$ Ibid. See also, Hansard, 25 January 1996, vol. 568, no. 32, col. 1214 in which the former Lord Chancellor, Lord Mackay said:

"Where either party to the proceedings is not prepared to take part in mediation, mediation is not suitable to the dispute, 
to mediation is prescribed by the court in certain circumstances. Although the parties do attend the mediation, there can be no compulsion on them to reach an agreement, and there is no coercion. ${ }^{61}$ However, where parties are legally aided, the failure to use mediation effectively may affect their entitlement to receive funding for any further proceedings. ${ }^{62}$

\section{(b) The information meeting}

Realising the fact that people facing marital breakdown need better information on a variety of matters currently available, the Consultation Paper thus, proposed that there should be a single first port of call for everyone wishing to initiate the divorce process. ${ }^{63}$

This first port of call is contained in s 8 of the FLA, 1996. It provides that a party who initiates the divorce must have attended an information meeting not less than three months before making the statement. ${ }^{64}$ Where both spouses jointly seek the divorce, both must attend a meeting, but need not do so together. ${ }^{65}$ Where one party has made a statement, the other party must (except in prescribed circumstances) attend an information meeting before making or contesting any application to the court with respect to a child of the family, in relation to property or financial matters. ${ }^{66}$ Therefore, it can be stated at this stage that it is mandatory to attend the information meeting except in specified circumstances, which are as yet undefined.

the parties and all the circumstances. I cannot see that a mediator could possibly regard mediation as suitable for a dispute where either party was not prepared to take part in it." Law Society Code of Practice for Family Mediation. Section 2, paras 2. 2-3. This Code is addressed to solicitors who practise as mediators in family disputes. The FLA, 1996 s 29; see also, Andy King, 'No Legal Aid Without Mediation - Section 29,' [1998] Fam Law 28, 331. Government Consultation Paper, Looking to the Future, 1993, para. 8.1.

The FLA, s 8 (2). One of the criticisms of the present divorce law is that a divorce can be obtained without proper consideration for the consequences and implications. See, the White Paper, para. 2. 21. The FLA, 1996, s 8 (4). Ibid., s 8 (5). 
In s. 8 'information meeting' means a meeting organised, in accordance with prescribed provisions for the purpose:

- $\quad$ of providing, in accordance with prescribed provisions, relevant information to the party or parties attending about matters which may arise in connection with the provisions of, or made under, this Part or Part III; and

- $\quad$ of giving the party or parties attending the information meeting the opportunity of having a meeting with a marriage counsellor and of encouraging that party or those parties to attend that meeting. ${ }^{67}$

An information meeting must be conducted by a person who is qualified and appointed in accordance with prescribed provisions, ${ }^{68}$ and will have no financial or other interest in any marital proceedings between the parties. ${ }^{69}$ In this regard the Lord Chancellor intends to assess a number of pilot projects before making a final decision as to the format. ${ }^{70}$ The information to be given in the meeting must, pursuant to section 8 (9), include:

- $\quad$ marriage counselling and other marriage support services;

- $\quad$ how the parties may acquire a better understanding of the ways in which children can be helped to cope with the breakdown of a marriage;

- $\quad$ the nature of the financial questions that may arise on divorce or separation, and services which are available to help the parties;

- $\quad$ protection available against violence, and how to obtain support and assistance;

- $\quad$ mediation;

- $\quad$ the principle of legal aid and where the parties can get advice about obtaining legal aid;

- $\quad$ the divorce and separation.

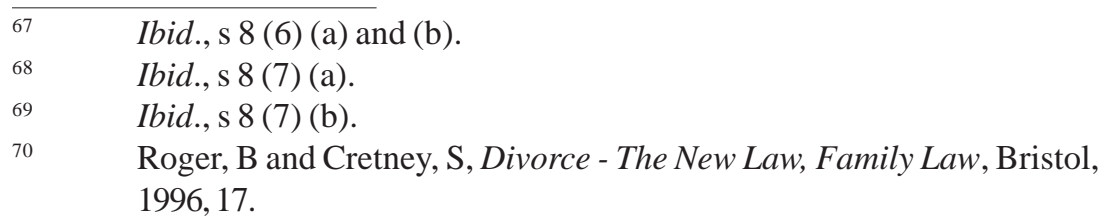


It is felt that this information meeting is vital, as couples should be given information relating to their disputes directly rather than through written information. This direct information is considered a better way of helping the couples understand the process of divorce, its consequences for adults and children and the services available to them. ${ }^{71}$ It is understood that, the provision on the information meeting as it is now, is only applicable to married parents. Thus, an issue can be made in the case unmarried parents involved in their child disputes, where, as far as this provision is concerned, information meeting is not available to them. ${ }^{72}$

The FLA, 1996 does not explain exactly how the individual meeting will be conducted, who will conduct it or how the information will be delivered. ${ }^{73}$ McCarthy ${ }^{74}$ in his article analysed the result of the pilot projects conducted with the above objective. The research findings, inter alia, suggested that information meetings need to be more interactive and responsive to attendees. The results also suggest that, lawyers continue to oppose the compulsory nature of the meeting as they regarded information meetings as a threat to the survival of their role in the divorce process. McCarthy, however, reassured that the impact of the meetings will be unlikely to change the lawyers' role. Indeed, according to him, there was evidence that they encouraged people to use solicitors. ${ }^{75}$

Fitzsimons, ${ }^{76}$ a pilot manager of the information meetings for the East Midlands, expressed the need to offer to the public an immediate, high quality and respectful service so as to minimise possible resentments and to make attendance at an information meeting a very positive

\footnotetext{
71 Parkinson, L, Family Mediation, 28.

72 Price, David, [1999] May, Fam Law 287.

73 Walsh, et al., suggested that emphasis should be given on how best to make giving the information more client-friendly. See, Walsh, Hodson \& Fisher, in Thorpe and Clarke, No Fault or Flaw: The Future of the Family Law Act 1996, Family Law, 2000, 39; see also, Cretney, Family Law, 80-81.

74 McCarthy, P, 'Providing Information - The Views of Professionals,' [2000] Fam Law 550.

75 McCarthy, P, 'Providing Information - The Views of Professionals,' [2000] Fam Law 550.

76 Fitzsimons, P, 'Managing an Information Meetings Pilot,' in Thorpe and Clarke, E, No Fault or Flaw: The Future of the Family Law Act 1996, Family Law, 2000, 13.
} 
experience. He then stressed the need to carefully select the information presenters who should be thoroughly well trained, be able to communicate clearly and be well aware of the boundaries within which they need to work. ${ }^{77} \mathrm{He}$ also stated in his conclusion that information meetings should be set up and offered by one agency. In this way, he said, "an overall high standard of service could be maintained, quality control exercised and there would be total accountability."78

\section{(c) Statement of marital breakdown ${ }^{79}$}

Under the FLA, 1996 instead of a petition for divorce or judicial separation as at present, a statement of marital breakdown will commence divorce proceedings. At least three months must elapse after the information meeting before the statement can be filed. ${ }^{80}$ On this new procedure, Cretney and Masson ${ }^{81}$ said, "Since it might be thought that any realistic prospects of reconciliation would have emerged during that three-month waiting period, making a statement three months after attendance at the information meeting may indicate a determination to have the relationship terminated rather than a willingness to reflect further on whether the marriage can be saved."

It is provided that either or both parties may file this statement. ${ }^{82}$ It must state that the maker or makers of the statement are aware of the purpose of the period of reflection and consideration and wish to make arrangements for the future. ${ }^{83}$ Court rules will specify the exact contents of the statement. ${ }^{84} \mathrm{~A}$ statement is ineffective for purposes of obtaining a

\begin{tabular}{ll}
\hline 77 & Ibid. \\
78 & Ibid. \\
79 & Section 6 (1) of the FLA states that a statement under s 5 (1) (a) is to be \\
& known as a statement of marital breakdown. According to Cretney, \\
& "the making of a statement of marital breakdown in the prescribed form \\
& is the key event in the process for the legal termination of marriage \\
& established by the FLA." \\
& The FLA, s 8 (2). \\
${ }_{80}$ & Cretney, S and Masson, The principles of Family Law, 346. \\
${ }_{81}$ & The FLA, 1996 s 5 (1) (a). \\
${ }_{82}$ & Ibid., s 6 (2) and (3). \\
${ }_{83}$ & Ibid., s 6 (4) and (5).
\end{tabular}


divorce order if made in the first year of marriage, continuing the present bar on divorce petitions presented within one year. ${ }^{85}$

As pointed out by Cretney and Masson ${ }^{86}$ it is submitted that this statement of marital breakdown has a number of important legal consequences. Firstly, the making of the statement starts the period of reflection and consideration running. Secondly, once a statement has been made, the court has power to make directions requiring the parties to attend meetings at which the facilities available for mediation will be explained to them. Thirdly, the court will, once a statement has been made, have power to make financial and other orders.

\section{(d) Period for reflection and consideration}

The period for reflection and consideration is introduced under the FLA, 1996. The marital proceedings under the FLA, 1996 commence on the filing of a statement of marital breakdown. ${ }^{87}$ There is then a period for the parties to reflect on whether the marriage can be saved and to have an opportunity to effect a reconciliation, and to consider what arrangements should be made for the future. ${ }^{88}$ This period begins 14 days after the court receives the statement in order to allow for service, unless there has been inordinate delay in service in which case the time can be extended. ${ }^{89}$

The period for reflection and consideration lasts nine months. ${ }^{90}$ However, if there is any child under $16^{91}$ or one party seeks time for

85 See, s 3 of the MCA, 1973 which provides that the couple is prevented from petitioning for a divorce within one year of marriage.

$86 \quad$ Cretney, S and Masson, The principles of Family Law, 344.

$87 \quad$ See, the FLA, 1996.

$88 \quad$ See, Official Report (H.L.) November 30, 1995, col. 703.

89 The FLA, s 7 (3). The date of receipt by the court was adopted in order to establish the date on which the period starts with "absolute certainty," the date when the statement is received by the court being a matter of recorded fact (whereas "there is no certain way of recording the date on which notice of the statement has been received by the other party, and in fact that party could go on denying receipt indefinitely.” per Lord Mackay of Clashfern, Official Report (H.L.) March 4, 1996, col. 10).

The FLA, s 7 (3).

Ibid., s 7 (11), (13). 
further reflection, there is an additional six-month period before an application for a divorce order can be made..$^{92}$ This six-month period does not apply if there is an occupation order or non-molestation order in favour of the applicant for the divorce order or a child of the family, ${ }^{93}$ or if the court is satisfied that delaying the divorce order would be significantly detrimental to the welfare of any child of the family. ${ }^{94}$

At the end of the nine-month period, or 15-month period if applicable, either party can apply for a separation order or divorce order. There is only 12 months in which to do so after the end of the nine or fifteen-month period for reflection and consideration, after which the proceeding lapse and a fresh statement must be made. It is possible for the parties to give notice jointly that they are attempting a reconciliation, whereupon time ceases to run. If the joint notice of attempted reconciliation lasts for more than 18 months, the proceeding lapses and there must be a new statement.

In summary, therefore, the minimum period which is to elapse between the start of the divorce process and the application for a divorce order is 12 months from attending the information meeting, but if one party objects to the divorce or there is a child the period will often be 18 months. ${ }^{95}$ This period follows the period of one year after marriage where no application for divorce can be initiated, a bar on divorce provided for in the MCA, 1973 and retained in the FLA, 1996.

\section{(e) Directions with respect to mediation and Adjournments for mediation}

Section 13 of the FLA, 1996 deals with directions with respect to mediation. It states that after the court has received a statement, it may give a direction requiring each party to attend a meeting arranged in accordance with the direction for the purpose of: (i) enabling an explanation to be given of the facilities available to the parties for mediation

\footnotetext{
$92 \quad$ Ibid., s 7 (10), (13).

93 Refer to ss 24, 39, 42 (1) of the FLA for the definition of an occupation or non-molestation order.

$94 \quad$ The FLA, s 7 (12).

95 Cretney, S and Masson, The principles of Family Law, 349.
} 
in relation to disputes between them; ${ }^{96}$ and (ii) providing an opportunity for each party to agree to take advantage of those facilities. ${ }^{97}$

A direction under s 13 may be given at any time, including in the course of proceedings connected with the breakdown of the marriage. ${ }^{98}$ Subsection (3) of s 13 provides a direction may be given on the application of either of the parties or on the initiative of the court. The parties are to be required to attend the same meeting unless (a) one of them asks, or both of them ask, for separate meetings; or (b) the court considers separate meetings to be more appropriate. ${ }^{99}$ Cretney ${ }^{100}$ commented that "such a direction may seem like a direction to participate in mediation but the FLA, 1996 is careful not to go as far as that." From the above sections, the parties will be directed to attend a meeting whereby all the facilities available are explained to them.

The court's power to adjourn any proceedings connected with the breakdown of a marriage includes power to adjourn (i) for the purpose of allowing the parties to comply with a direction under s $13 ; 101$ or (ii) for the purpose of enabling disputes to be resolved amicably. ${ }^{102}$ When the court decides whether or not to allow an adjournment for either of the purposes set out above, it must have regard in particular to the need to protect the interest of any child of the family. ${ }^{103}$ If the court does adjourn any proceedings connected with the breakdown of the marriage for either of those purposes, the period of the adjournment must not exceed the maximum period prescribed by rules of court. ${ }^{104}$ Thus, ss 13 and 14 give the court specific power to adjourn proceedings at an interlocutory stage to consider the opportunity of the parties to take part in mediation. Walsh,

\footnotetext{
96 The FLA, s 13(1) (a).

$97 \quad$ Ibid., s 13 (1) (b).

98 Ibid., s 13 (2); The meaning of 'connected proceedings' is contained in s 25 and includes proceedings under Parts I to IV of the Children Act, 1989 and for an order under Part IV of the FLA, 1996.

$99 \quad$ The FLA, 1996 s 13 (4) (a) and (b).

100 Cretney, S and Masson, The principles of Family Law, 352.

101 The FLA, s 14 (1) (a).

$102 \quad$ Ibid., s 14 (1) (b).

103 Ibid., s 14 (2).

$104 \quad$ Ibid., s 14 (3); The rules stated in the subsection have not yet been formulated.
} 
et. al., ${ }^{105}$ view that such power to adjourn proceedings is suitable at First Appointment and Financial Dispute Resolution hearings. They also observed that some courts are keen to have the power to adjourn, thus, they suggested that it should be introduced to help parties and the courts.

\section{CRITICISM AGAINST THE NEW REFORM}

At present, the position of the non-fault principle introduced under the FLA, 1996 is very uncertain. In June 1999, the UK Government announced that implementation of the new law was indefinitely suspended. The reason given was that the pilot scheme that was carried out by Professor Janet Walker of the University of Newcastle, to test the provision of information meetings had been disappointing. The result of the pilot study showed only 7 per cent of those attending the pilots had been diverted into mediation and 39 per cent of those attending had reported they were more likely than before to go to a solicitor. According to Brown ${ }^{106}$ the no-fault basis would be withdrawn and the Lord Chancellor would review the position in the future. ${ }^{107}$ For the time being, he said, divorce practitioners will continue with the previous divorce law. ${ }^{108}$ The Lord Chancellor stated that before the new law could be implemented the Government must be satisfied that the new arrangements for divorce would work in practice.

105 Walsh, H and Fisher, T, in Thorpe and Clarke, E, No Fault or Flaw: The Future of the Family Law Act 1996, Family Law, 2000, 40.

106 Brown, $\mathrm{H}$ and Marriott, A, ADR Principles and Practice, 224.

107 It might be interesting to look at some of the comments made on position of no-fault divorce in the UK legislation. Sir Thomas BoydCarpenter in the Lord Chancellor's Advisory Board on Family Law Annual Report concluded, "While the no-fault divorce plans were 'not perfect,' they were good enough to put into practice and subsequently refine." He then claimed "the abandonment of part two was 'deeply disappointing' as it would mean that couples would be forced to continue to find acrimonious grounds in order to obtain a divorce in less than two years.” Rosemary Carter, previous chairwoman of the Solicitors Family Law Association which strongly in favour of no-fault divorces, said, "a couple who have decided to part amicably should not be forced to find grounds of acrimony." See, http:// www.ukcle.ac.uk/event/ Ibid. 
The Lord Chancellor eventually announced that Part II of the FLA 1996 would be repealed. Critics said that the parties would never spend the period for reflection in that process, as they would already have decided on divorce by the time it was reached. The Solicitors' Family Law Association during the passage of the Bill had warned that the new law was cumbersome, confusing and would create delay and uncertainty, which was contrary to the best interests of divorcing couples and their children. Many people said it was unfair for a person to be divorced on a statement of marital breakdown with no chance to defend or to know what alleged fault, which had generated the action. There are however, peoples who are very positive that the no-fault principle will take place. For example, Bainham ${ }^{109}$ in his article found out that there was general agreement the no-fault divorce should be introduced without delay, ${ }^{110}$ as this is very important to achieve the notion of saving marriage. ${ }^{111}$

Although the proposed new law was not implemented, reform is still required because the law in force is both unsatisfactory and confusing. ${ }^{112}$ The Lord Chancellor's Advisory Board on Family Law in its final report in July 2001 regretted the missed opportunity to reform divorce, and urged that serious consideration be given to replacing the current adversarial, partly fault-based divorce regime. It said that the serious defects in the current law identified by the Law Commission still

109 See, Andrew Bainham, Reviews Column, [2000] August, Fam Law 578; There have been some comments made by lawyers who are positive about the future of no-fault divorce in the UK's legislation quoted from the Law Gazette (http://www.lawgazette.co.UK/features/ archivearticle.asp). For example, Mr Massey considers no-fault divorce as a way forward for couple. He said, "There will be future legislation on the matter, but I think it's been put on the backburner for the time being, as the Government has realised the cost of the information meetings is far higher than expected." Mr Harper said, "No-fault divorce was an option for couples to divorce with dignity. Unfortunately it had become so muddled and unworkable that the baby had to be thrown out with the bathwater.”

$110 \quad$ Ibid.

111 McCarthy, Walker, Hooper, 'Saving Marriage - A Role for Divorce Law,' [2000] June, Fam Law 412.

112 Standley, Kate, Family Law, Palgrave Macmillan Ltd., London, 2004, 142-143. 
remained. In particular, allegations of adultery and unreasonable behaviour caused unnecessary conflict between the parties, and their distress and anger impacted on the children. ${ }^{113}$

\section{CONCLUSION}

The above discussion particularly on the development of reconciliation provisions and conciliation schemes in England shows that efforts to improve this aspect of the law have always been in existence. Starting from the 1970s conciliation in England has experienced different stages of development and improvement. The current Family Law Act, which was enacted in 1996, gives special recognition to mediation as an alternative means for the resolution of family disputes. However, observations and opinions suggest that much more need to be researched and developed before it becomes a reality. The FLA, 1996 as a whole is aimed at creating an environment in which the grave matter of marital dissolution is considered differently from the present, but to achieve this there would need to be a radical change in how the various professional groups offer their services and co-operate to guide people through the divorce maze, and, indeed, a more general cultural shift. Traditionally, people considering divorce go to see a solicitor as their first public port of call. This, however, will be changed with the introduction of $s$ of the FLA, 1996. It may be difficult at the beginning for the people involved in the divorce process to get used to the changes introduced under the FLA, 1996. Should Part II (which contains s 8) of the FLA, 1996 be repealed, the substitute has to be a better piece of legislation, as the social reality of divorce is so crystal-clear, in addition to the huge amount of work and effort that has been put into realising the FLA, 1996. It is gratifying to know that the Lord Chancellor, in announcing the Government proposal to repeal Part II of the FLA, 1996 emphasised the Government's commitment to achieving the principles embodied in Part I of the FLA, 1996. It is viewed that all these efforts should not be wasted but be considered as a starting point towards a better change although we all know that it is not an easy task to find a coherent, workable and understandable new divorce law. 